\title{
Evaluation of prenatal care according to indicators for the Prenatal and Birth Humanization Program
}

Carla Gisele Vaichulonis 1

iD https://orcid.org/0000-0001-6721-1820

Rodrigo Ribeiro e Silva 2

iD https://orcid.org/0000-0001-9112-6511

Andreza Iolanda Apati Pinto 3

iD https://orcid.org/0000-0002-1455-0017

Indianara Rodrigues Cruz 4

iD https://orcid.org/0000-0001-7982-4093

Ana Clara Mazzetti 5

(iD) https://orcid.org/0000-0003-2590-7146

Luciane Haritsch 6

iD https://orcid.org/0000-0002-2973-8311
Karine Vlastuin dos Santos 7 https://orcid.org/0000-0002-8109-2167

Guilherme Schroeder Stepic 8

https://orcid.org/0000-0003-0768-3134

Larissa Cano de Oliveira 9

iD https://orcid.org/0000-0002-8785-4089

Melquizedek Félix da Silva 10

iD https://orcid.org/0000-0002-9460-9794

Jean Carl Silva 11

(iD https://orcid.org/0000-0002-3094-8180

1,10 Departamento de Ensino e Pesquisa. Maternidade Darcy Vargas. Rua Miguel Couto, 44. Joinville, SC, Brasil. CEP: 89.202-190. E-mail: carlinhanurse@yahoo.com.br 2-9,11 Universidade da Região de Joinville. Joinville, SC, Brasil.

\begin{abstract}
Objectives: to evaluate prenatal care provided to low-risk pregnant women users of the Sistema Único de Saúde (SUS) (Public Health System) in the city of Joinville, SC.

Methods: this is a cross-sectional observational study carried out from March 2018 to February 2019, through interview and analysis of the Pregnant Card of puerperal over 18 years old, from Joinville, who underwent prenatal care at SUS, excluding recent given up puerperal. Prenatal care was evaluated according to the recommended criteria by the Prenatal and Birth Humanization Program.

Results: 683 mothers were interviewed. The criteria with the highest levels of adequacy were accessibility (99.6\%), early initiation on prenatal care (92.7\%) and 6 or more consultations $(87.1 \%)$ and the criteria with the lowest rates of adequacy were the set of guidelines (17.7\%) and the third and first trimester exams (42.5\% and $63.5 \%$ respectively).

Conclusion: it is concluded that the prenatal care provided by SUS in the city of Joinville, despite the almost universal accessibility, the early onset and the prevalence of puerperal women with more than 6 consultations, showed a sharp decline in the analysis of the recommended indicators.

Key words Health evaluation, Maternal and child health, Prenatal care
\end{abstract}

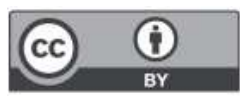




\section{Introduction}

Prenatal care (PNC) is one of the pillars of maternal and child healthcare, whose relevance in reducing morbidity and mortality in this population is already established 1-3. The absence or inadequacy of care during the PNC period can have serious consequences for the health of the mother and fetus. ${ }^{1-5}$

Studies conducted in 2015 and 2012 in the city of Joinville, analyzed respectively 4,206 puerperal medical records and 921 babies admitted to a Neonatal Unit, concluded that pregnant women who had 6 or fewer PNC consultations had more complications during pregnancy and the fetuses had low birth weight, higher risk of prematurity and neonatal death.4,5 Corroborating this result, other studies carried out in 2011 and 2013 in the cities of São Paulo and Teresina, which analyzed 2,404 pregnant women and 208 puerperal women, respectively, clearly emphasized the relationship between PN care and the newborn's well-being. 1,6

According to the World Health Organization (WHO), it is estimated that, in 2015, 303 thousand women died from preventable causes related to pregnancy, 2.7 million babies died in the neonatal period and 2.6 million fetuses were stillborn.7 In Brazil, between 1990 and 2015, there was a decrease in the maternal mortality ratio from 141 to 60 deaths per 100 thousand live births, representing a reduction of $58 \%$. Regarding neonatal mortality rate between 2000 and 2015 , there was a decrease from $16.7 \%$ to $9.4 \% .8,9$

These exponential declines occurred due to significant advances in the public health policies since the $90 \mathrm{~s}$, including the implementation of the Sistema Único de Saúde (SUS) (Public Health System), the evolution of vaccination coverage, the implementation of the National Information System, and the implementation of expressive health programs such as the Programa de Agentes Comunitários de Saúde (PACS) (Community Health Agents Program) and Estratégia Saúde da Família (ESF) (Family Health Strategy). 10

In 2016, world leaders gathered in the United Nations Summit in order to analyze and implement the Sustainable Development Goals (SDGs) for 2030, in which WHO idealizes, among others, access to adequate healthcare for all women and newborns during pregnancy, childbirth and the puerperium, aiming to reduce preventable maternal and neonatal mortality, as well as universal access to health services. 11

The current programs from the Ministry of Health, such as the Prenatal and Birth Humanization
Program (PNBHP), Rede Cegonha (RC) (Stork Network) and Atenção ao Pré-Natal de Baixo Risco (Prenatal Low Risk Care), implemented in 2000, 2011 and 2012, respectively, advocate the integrality of healthcare provided for women and newborns', providing the objectives of reducing morbidity and mortality rates, ensuring accessibility to the health services, being welcomed by the staff and having quality in the PN care, childbirth and puerperium. $3,12,13$

According to PNBHP, an ideal PN care corresponds to the fulfillment of the following recommendations: early PN care until the $4^{\text {th }}$ month of pregnancy; minimum of six visits for a full-term pregnancy; application of tetanus vaccine - immunizing dose or booster dose in women already immunized; educational activities; classification of gestational risk and guarantee of access to the reference unit for outpatient and / or hospital care for high-risk pregnancies, and laboratory tests in the first and third trimester. 12

Given the lack of evaluation studies on the quality of health services, it is expected that this study will provide data for the evaluation and improvement of PN care in the city of Joinville.

\section{Methods}

This is a randomized cross-sectional study carried out between March 2018 and February 2019 with a focus on the evaluation of PN care in Joinville, SC; the study subjects were low-risk puerperal women who had their babies at the Darcy Vargas Maternity in the city of Joinville, SC.

The stratified random sample was determined by the Randomized Research program by selecting 10 days per month over a 12 -month period. On the selected days, interviews were applied to all puerperal women who had the inclusion criteria for this study: age 18 years or more, carried out low-risk PN care entirely in the public health in the city of Joinville, have at hand the Pregnant Card, speak and understand Brazilian Portuguese language and accept to voluntarily participate in the study, by reading and agreeing to the Termo de Compromisso Livre e Esclarecido (TCLE) (Informed Consent form), being told about the free will to leave the research at any time. The withdrawal from participating in the research during the interview was an exclusion criterion.

The confidentiality and secrecy of the information regarding the content and identification of the puerperal women was ensured, as well as anonymity at the time of publication in accordance with 
Resolution of the National Council of Health number $466 / 2012$. The data collecting was carried out only after the approval by the Research Ethics Committee of the Regional Hospital Hans Dieter Schmidt under the Certificate of Presentation for Ethical Appreciation - CAAE number 82366218.1.0000.5363 and Consubstantiated Opinion number 2.480.567 on January 31, 2018.

The data sources of the study embraced: interview directed to the puerperal women and analysis of the data transcribed in the Pregnant Card.

The variables collected by interview for the sociodemographic characterization of the studied population were: age, education, referred race, family income, number of people living with that income, marital status, paid activity, and previous and current obstetric history. Information was collected about participation in educational activities and / or guidance received about pregnancy, childbirth and puerperium, which are: what are the types of delivery (cesarean delivery and normal delivery) and which is the best for the women and newborns; recognition of abnormal signs of pregnancy; importance of breastfeeding for women and newborns; contraceptive methods after childbirth; gynecological check-up consultation after 40 days of delivery; importance of consulting the newborn in his/her first week of life.

To evaluate the care process, the variables collected from the Pregnant Card were: gestational age (GA) of the first consultation, expressed in weeks; total number of consultations carried out in the PNC; note on immunizing dose or booster of tetanus vaccine; ABO Rh, Hb / Ht, VDRL, Anti-HIV, Urine and Fasting Glycemia tests.

The evaluation of the PN care quality occurred by analyzing the individual criteria suggested by PNBHP and the PNBHP Process indicators, based on the data available on the Pregnant Card and interviews, which were:

Criteria evaluated according to PNBHP:

1. Beginning of the PNC until the fourth month of pregnancy;

2. Minimum of $6 \mathrm{PN}$ consultations;

3. Immunizing dose or booster of tetanus vaccine;

4. Pregnant women who participated in educational activities or received guidance during PN consultations;

5. 1st quarter exams: $\mathrm{ABO} / \mathrm{Rh} ; \mathrm{Hb} / \mathrm{Ht}$; anti-HIV; VDRL; Type 1 urine and fasting glycemia;

6. 3rd quarter exams: VDRL; Type 1 urine and fasting glycemia;

Process Indicators according to PNBHP:

1. Percentage of pregnant women who had their first consultation until the fourth month of pregnancy;

2. Percentage of pregnant women who attended six PN consultations;

3. Percentage of pregnant women who received the immunizing dose of the tetanus vaccine;

4. Percentage of pregnant women who received guidance and participated in educational activities;

5. Percentage of pregnant women who had six PN consultations and all the tests were provided for PNBHP;

6. Percentage of pregnant women who had six PN consultations, all basic exams and the immunizing dose of tetanus vaccine.

Concurrently with the collection, the data were digitalized in an electronic database with double entry, to check for concordance and possible typing errors. Statistical Package for the Social Sciences Software (SPSS), version 21.0 was used for the statistical analysis of the data. All variables were analyzed descriptively, thus, continuous variables (numeric) were studied by calculating averages and standard deviations. For qualitative variables, absolute and relative frequencies were calculated.

\section{Results}

The study included 683 puerperal women whose average age was 26.1 years \pm 5.6 years with a higher prevalence between 20 to 29 years of age $61.7 \%$ $(\mathrm{n}=422)$, the white race was the most referred 63.6 $\%(n=434)$, and the prevalent schooling was 8 to 11 years of studying $77.7 \%(n=530)$. More than half of the studied population had a paid activity $54.6 \%$ $(\mathrm{n}=54.6 \%)$, were in a stable marital relationship $66.5 \%(\mathrm{n}=454)$, had a family constituted between 4 and 6 people $58.2 \%(n=397)$ and $63 \%$ of the pregnancies were not planned $(n=430)$. These data were grouped in Table 1.

In Figure 1, it is observed that the criteria with the best adequacy ratios were the coverage of prenatal care with $99.6 \%(\mathrm{n}=683)$, the beginning of the PN care until the fourth month was of $92.7 \%$ $(n=633)$ and the performance of 6 or more prenatal consultations with $87.1 \%(n=595)$ of adequacy. The criteria with the lowest suitability indexes were the first quarter exams with $63.5 \%(n=433)$, the third quarter exams with $57.5 \%(\mathrm{n}=393)$ and receiving the set of 6 guidelines during the PN care was reported by $17.7 \%(n=120)$ of the interviewees.

Figure 2 shows the indexes referring to the Guidelines performed during the PNC, which proves that the most reported indicators were abnormal signs of pregnancy $81.5 \%(n=557)$, breastfeeding 
Table 1

\begin{tabular}{|c|c|c|}
\hline Variables & $N=643$ & $\%$ \\
\hline \multicolumn{3}{|l|}{ Age (years) } \\
\hline $\bar{X} \pm S D$ & $26.1 \pm 5.6$ & \\
\hline $18-19$ & 73 & 10.7 \\
\hline $20-24$ & 234 & 34.2 \\
\hline $25-29$ & 188 & 27.5 \\
\hline $30-34$ & 125 & 18.3 \\
\hline$\geq 35$ & 63 & 9.3 \\
\hline \multicolumn{3}{|l|}{ Schooling (years) } \\
\hline Illiterate & 1 & 0.1 \\
\hline$\leq 7$ & 57 & 8.3 \\
\hline $8-11$ & 530 & 77.7 \\
\hline$\geq 12$ & 95 & 13.9 \\
\hline \multicolumn{3}{|l|}{ Skin color } \\
\hline White & 434 & 63.6 \\
\hline Mixed / Black & 226 & 33.1 \\
\hline Others (yellow, indigenous) & 23 & 3.3 \\
\hline \multicolumn{3}{|l|}{ Family income (MW) } \\
\hline No income / Not informed & 44 & 6.5 \\
\hline$\leq 1 \mathrm{MW}$ & 34 & 5.0 \\
\hline $1.1-1.9 \mathrm{MW}$ & 181 & 26.5 \\
\hline $2-4.9 \mathrm{MW}$ & 368 & 53.9 \\
\hline$\geq 5 \mathrm{MW}$ & 56 & 8.1 \\
\hline \multicolumn{3}{|l|}{ Profession } \\
\hline Paid & 373 & 54.6 \\
\hline Unpaid & 310 & 45.4 \\
\hline \multicolumn{3}{|c|}{ Number of people living with income } \\
\hline $\bar{X} \pm S D$ & $4.4 \pm 1.3$ & \\
\hline$\leq 3$ & 253 & 37.0 \\
\hline $4-6$ & 397 & 58.2 \\
\hline $7-9$ & 33 & 4.8 \\
\hline Stable marital status & 454 & 66.5 \\
\hline \multicolumn{3}{|l|}{ Previous reproductive history } \\
\hline Previous cesarean section & 256 & 37.5 \\
\hline $1^{\text {st }}$ gestation $\leq 18$ years & 232 & 34.0 \\
\hline Abortion & 108 & 15.8 \\
\hline Infertility & 59 & 8.6 \\
\hline Fetal or perinatal death & 28 & 4.1 \\
\hline \multicolumn{3}{|l|}{ Current reproductive history } \\
\hline Unplanned pregnancy & 430 & 63.0 \\
\hline UTI & 166 & 24.3 \\
\hline SHDP without treatment & 63 & 9.2 \\
\hline GDM without treatment & 24 & 3.5 \\
\hline
\end{tabular}

Data presented as average and standard deviation; MW = Minimum Wage; UTI = Urinary Tract Infection; SHDP = Specific Hypertension Disease in Pregnancy; GDM = Gestational Diabetes Melitus.

$64.9 \% \quad(n=443)$, and baby consultation $58.3 \%$ $(\mathrm{n}=398)$. The least mentioned criteria were gynecological check-up consultation $50.7 \%(n=346)$, types of delivery $49.7 \%(n=339)$, and postpartum contraception $36.6 \%(n=250)$. Only $22.1 \%(n=151)$ of the interviewees reported participation in a Pregnant
Women Group in the PN Health Unit.

The analysis of Figure 3 refers to the criteria of the tests recommended by PNBHP, collected from the interviewees' Pregnant Cards. The ABO / Rh and anti-HIV tests were performed by $90.7 \%(n=620)$ of the pregnant women, followed by the $\mathrm{Hb} / \mathrm{Ht}$ test, 


\section{Figure 1}

Criteria to perform prenatal care conceived by the Prenatal and Birth Humanization Program. Joinville, 2019.

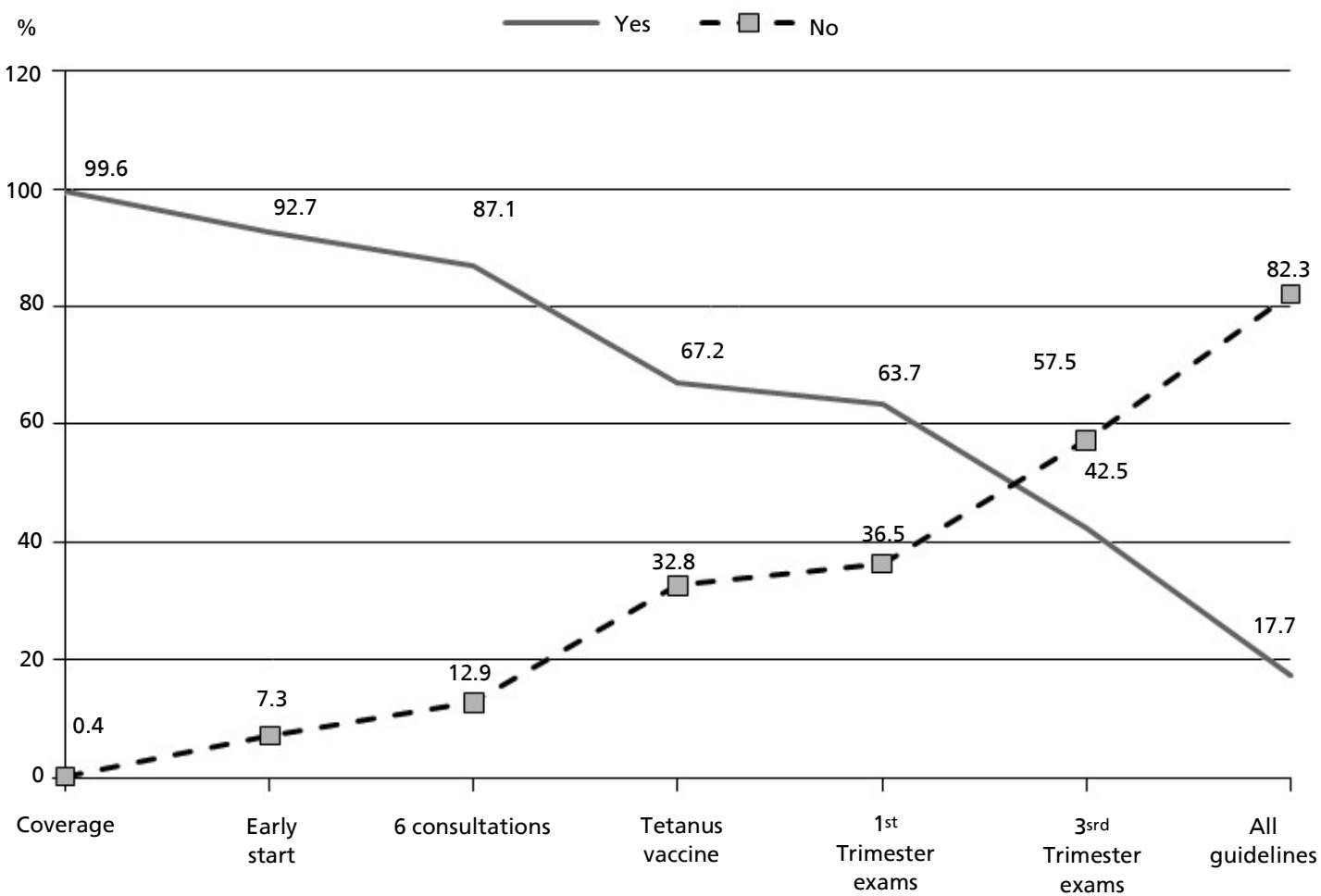

\section{Figure 2}

Orientations received during prenatal care, mentioned by the interviewees. Joinville, 2019.

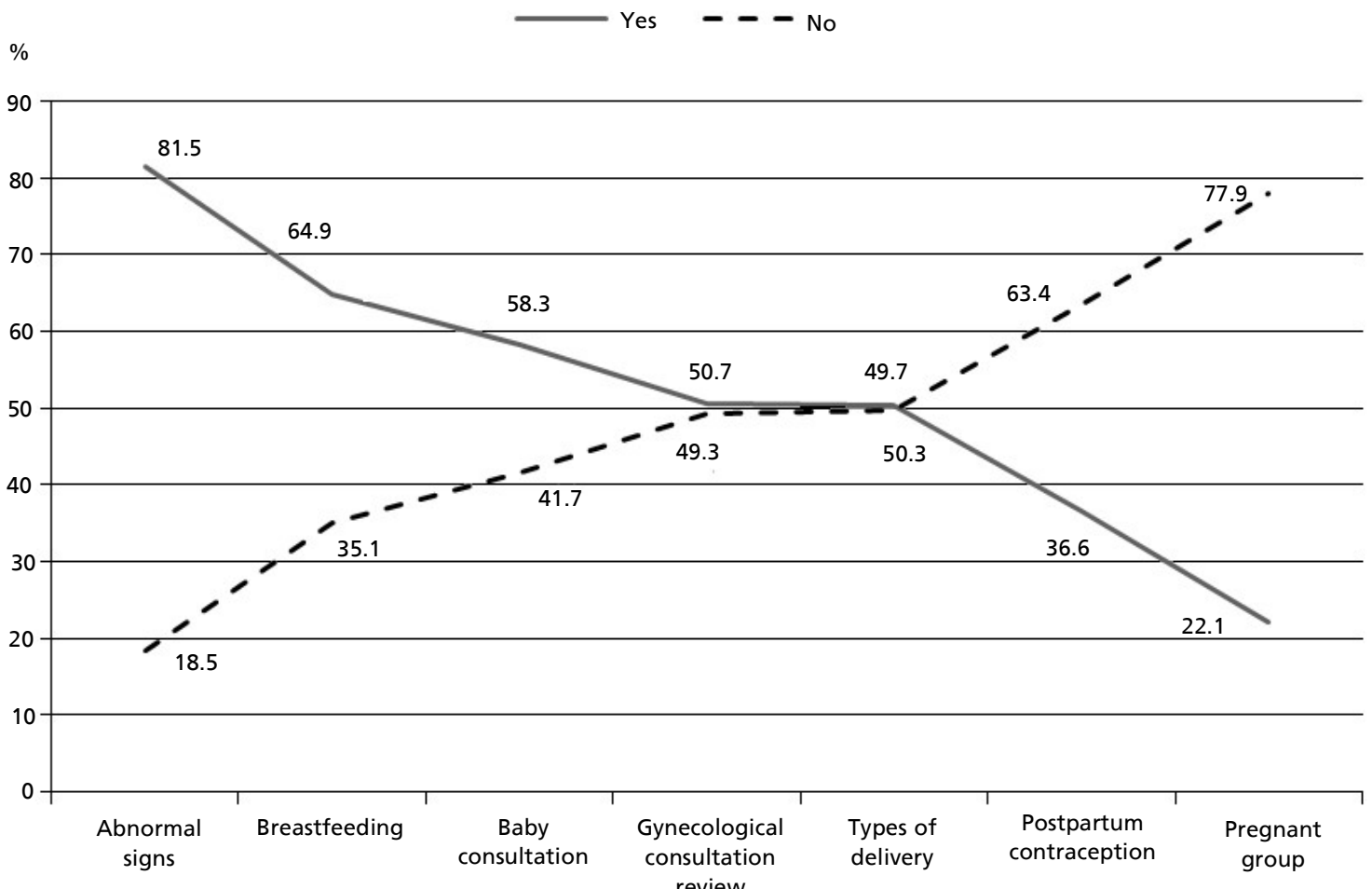


Figure 3

Prenatal exams according to data on the Pregnant Card. Joinville, 2019.

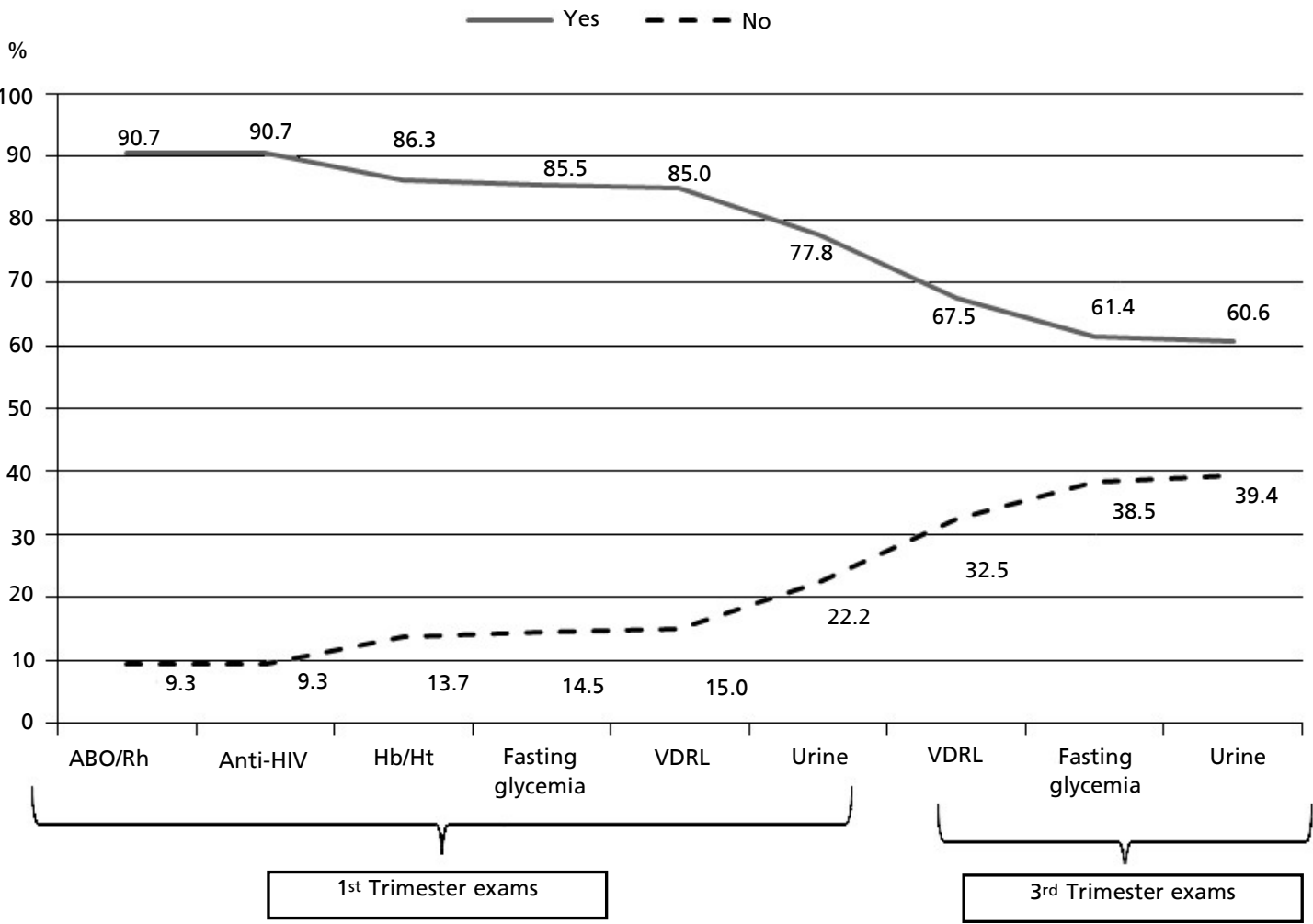

with a percentage of $86.3 \%(n=589)$, both made during the first trimester of pregnancy. The tests with the lowest prevalence rates were those performed in the third trimester of pregnancy, called VDRL, fasting glycemia and Type 1 Urine, with percentages of $67.5 \%(n=461), 61.4 \%(n=419)$ and $60.6 \%$ $(\mathrm{n}=413)$, respectively.

The analysis of the indicators of PN Care Process, recommended by PNBHP and shown in Figure 4, demonstrates that the indicators with the highest prevalence in adequacy are: the beginning of prenatal care until the fourth month of pregnancy, 6 consultations or more during prenatal care, and tetanus vaccination, with the respective percentages of $92.7 \%(n=633), 87.1 \%(n=595)$ and $67.2 \%$ $(\mathrm{n}=459)$. When joining two or more indicators, an exponential drop in adequacy can be seen. The percentage of puerperal women who had at least six visits of PNC and all tests provided by PNBHP was $29.6 \%(n=202)$. Adding the item of receipt of tetanus vaccine to these indicators, this percentage drops to $22.7 \%(n=155)$. The lowest percentage corresponds to the receipt of the set of 6 guidelines, mentioned by only $17.7 \%(n=120)$ of the interviewees.

\section{Discussion}

The main aspect when evaluating a program is to ensure that the information from this evaluation improves interventions and health care for the study population. Some findings of this study are worrisome, when considering that the analysis of the quality of PNC consisted on evaluating rules on PN support, that is, the performance of the procedures recommended by the Ministry of Health for an effective PNC. 14

When analyzing the results regarding to the criteria recommended by the PNBHP, it is observed that, although the coverage of PN care in Joinville was almost universal, reaching $99.6 \%(\mathrm{n}=683)$ of the studied population, the late start of prenatal care, after the fourth month of pregnancy, was observed in $7.3 \%(n=50)$ of the interviewed mothers.

The early initiation of $\mathrm{PN}$ care grants access to diagnostic and therapeutic methods for various conditions with critical consequences for maternal and child health, such as hypertension, diabetes, anemia, and syphilis or HIV infection. In addition, an estimated gestational age is more accurate in the 


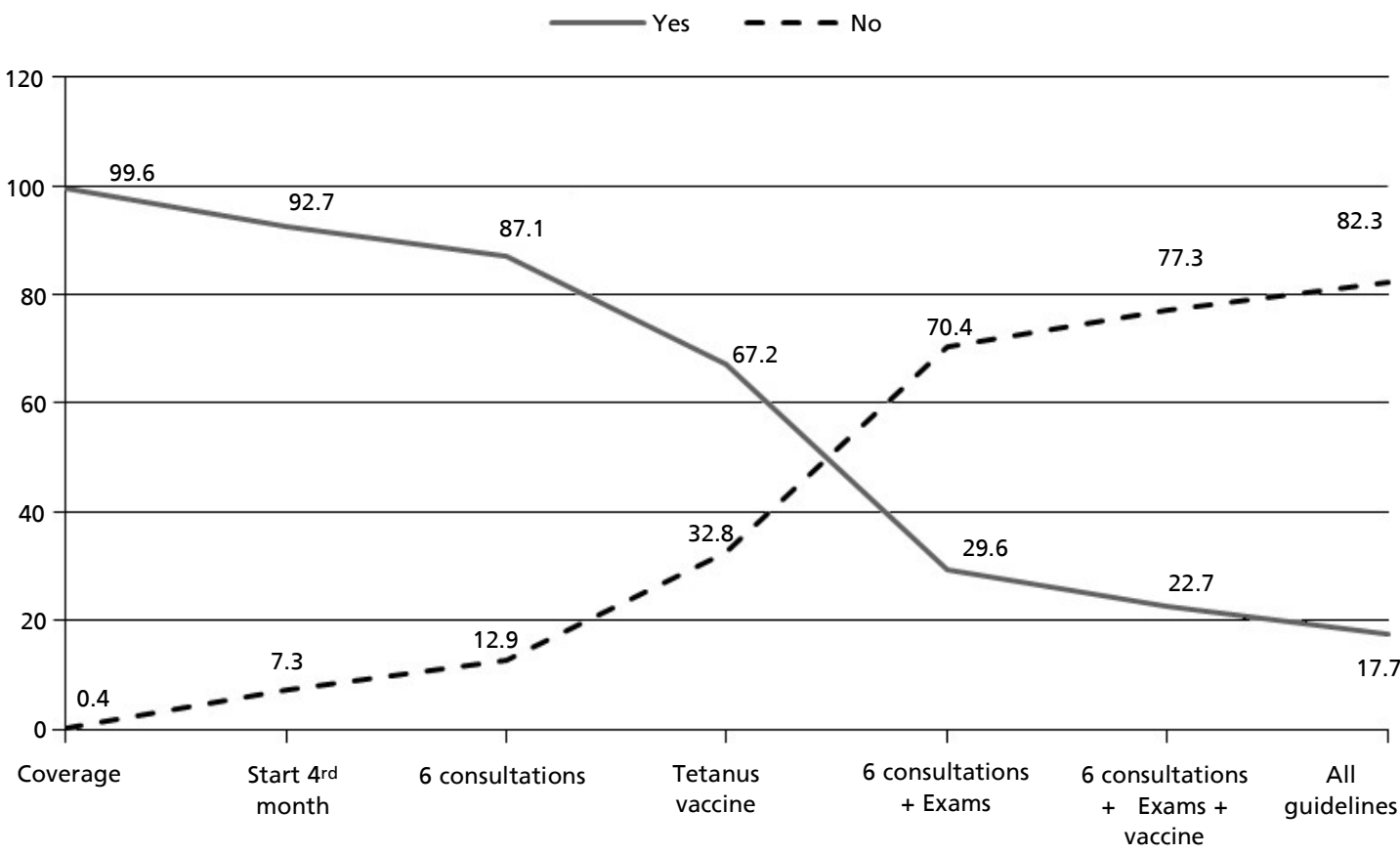

first quarter, ensuring better monitoring of fetal growth. 2,15

The analysis of the number of consultations that are greater than or equal to 6 throughout the PNC shows an inadequacy of $12.9 \%(n=88)$ of the interviewees, which means that they had less than 6 prenatal consultations. The decision on the ideal number of consultations is crucial for the elaboration of care protocols and the delineation of health resources. Theoretically, a larger number of consultations may mean more chances of receiving guidance and preventive care, especially in higher-risk pregnancies, with a greater probability of affecting perinatal outcomes. 6,16

Observing the criterion related to tetanus vaccination during PN care, it is noted that $32.8 \%(\mathrm{n}=256)$ of the interviewees did not have this information re interviewees registered on their Pregnant Card. With the Neonatal Tetanus Elimination Plan, in 1992, epidemiological surveillance actions were implemented identifying risk groups and indicating vaccination to all women of childbearing age (15 to 49 years old), pregnant or not. 17

Immunization is carried out for the purpose of preventing neonatal tetanus and for the protection of pregnant women, and the National Immunization
Program recommends immunization in $100 \%$ of pregnant women. ${ }^{16,17}$

Regarding the criterion that evaluates the realization of the 6 consultations analyzed in this study, $22.1 \%$ of the interviewees reported that they participated in a group of pregnant women, however only $17.7 \%(n=120)$ of the interviewees reported that they received the set of 6 orientations. Considering the universality of access $(99.6 \%)$ and the predominance of respondents who had 6 or more PN consultations (87.1\%), a higher adequacy index of these variables was expected.

It is undeniable that PN care is recognized as a privileged space for the dissemination of information, increasing the knowledge of women. Therefore, the need to strengthen educational activities through the use of light technologies is pointed out, as a unique scenario of health education, relevant and sensitive, stopping gravitating only to clinicalobstetric procedures. 18

For efficient, authentic, and quality health care, it is important that health professionals consider essential aspects of the human relationship in their work, such as conversation, listening, welcoming touch, sharing ideas, demonstration of real concern, and the expression of affection, paying attention to 
wishes, desires and claims made by the pregnant women. 19

When evaluating the recommended criteria related to routine exams in the first and third trimester, it is noted that the exams in the first quarter are presented with lower rates of inadequacy in relation to the exams in the third quarter, with percentages of inadequacy ranging from $9.3 \%$ for the $\mathrm{ABO} / \mathrm{Rh}$ exam, to $22.2 \%$ for Type 1 Urine. The third trimester exams maintain the growing curve of inadequacy, with percentages of $32.5 \%$ for VDRL and $39.4 \%$ for Type 1 Urine.

The lack of results of essential routine exams for pregnant women characterizes the loss of opportunity for diagnosis and treatment of damage susceptible to control, anemia, urinary tract infection, and syphilis and HIV infection, being considered causes of some unfavorable perinatal outcomes and for which there are concrete actions. 2,20

Analyzing the indicators of the PN care process, it is observed that $7.3 \%(n=50)$ of the interviewed mothers began their PNC after the fourth month of pregnancy. This fact is reported in other studies: in 2012 , a robust national survey was carried out, with 23,940 puerperal women; in 2008 an analysis was conducted in Rio de Janeiro, with 2,422 pregnant women; and in 2016, in the state of Sergipe, 768 mothers participated in a similar study - the rates of inadequacy varied by $24.2 \%, 25 \%$ and $43 \%$ respectively.20,21,22

Despite the inadequacy of this item, when comparing to other studies, there is an improvement in early access to prenatal care. It is permissible that these results comprise divergent determinants, pertinent to the particularities of the population of scope and the organization of the network of health services in each location.

In regard to the number of consultations, it was obtained an inadequacy percentage of $12.9 \%$ of puerperal women who had less than 6 consultations in the PN care. The low coverage of consultations has also been identified in other national studies, such as a survey conducted in Rio Grande in 2007 with 2,557 puerperal women; analysis carried out in Espírito Santo in 2008 with 1,380 women; and another examination between the South and Northeast, carried out in 2007 with 4,078 women; the results showed inadequacy of $24.7 \%, 33 \%$ and $75 \%$, respectively, corroborating the conclusions of the present study. $23-25$

Regarding the tetanus immunization indicator, an inadequacy percentage of $32.8 \%(n=256)$ was obtained among the studied population, representing a coverage below $70 \%$. This result is corroborated by other studies, such as the one carried out in Espírito Santo in 2013 with 742 mothers, in Rio de Janeiro in 2008 with 2,353 mothers, and another in São Paulo performed in 2013 with 2,404 mothers, in which inadequacies were identified in $41.3 \%, 46 \%$ and $67.2 \%$, respectively. $1,20,26$

However, the registration of this information was much lower than that found in a study conducted in Caxias do Sul in 2001 with 720 puerperal women,27 which measured more than $90 \%$ of tetanus vaccine coverage. This study considered the information taken from the Pregnant Card, from the medical registration and the puerperal women themselves, possibly because the sources of information were added to obtain the results - which is not the case in this study, because it is considered only the Pregnant Cards as a data source for this indicator.

Regarding the indicator of educational activities, there is a decrease in suitability for items ranging from $81.5 \%$ for abnormal signs of pregnancy to $36.6 \%$ corresponding to the information about the types of delivery. Besides, only $17.7 \%$ of respondents reported having received all 6 guidelines. The orientations on childbirth and gynecological checkup consultation after 40 days were mentioned by less than $50 \%$ of the mothers. This result is similar to that found in the evaluation of other services. 28,29

Regarding the indicators that analyze the quality of the PNC by grouping the criteria, characterizing the totality and effectiveness of the PN care, there is, in the sum of 6 consultations and all exams, an adequacy index of $29.6 \%$. When adding the tetanus vaccine to this indicator, the percentage drops to $22.7 \%$. Other studies corroborate this result, reflecting that the biggest challenge in the consolidation of an efficient PN care stems from the fulfillment of the set of criteria, and not only from the isolated activities. ${ }^{26,30}$

Despite the undeniable advances, it is perceived that the public health system in the city of Joinville has not yet reached all the necessary transformations to build the care model recommended by SUS. Furthermore, the limitations of this study are recognized since the secondary information comes from the Pregnant Cards.

The absence of proper record of information is an obstacle to the planning and organization of health services. As data comes from secondary sources, there is no guarantee that there are no errors and mistakes, both when completing the Pregnant Cards, considering that it is performed by several professionals, as well as in the analysis, understanding, transcription and typing information into the database. 
There are also limitations regarding the information related to the orientations received during prenatal care, since the self-report allows multiple interpretations and memory bias. In addition, the objective is limited, as it evaluates the prenatal care process excluding variables related to the physical structure of health facilities and impact indicators, such as maternal and child mortality.

However, it must be considered that the results presented in this study were based on objective parameters of prenatal care, seen as essential for improving women and children's health.

When evaluating the quality of prenatal care, it is important to emphasize whether the attendance and the services offered to pregnant women exceed only the number of consultations and standard examinations performed by the health team, in other words, it is essential to note the efficiency of this process, considering its complexity and multi-factoriality.

The findings of this study show that, despite the universality of coverage of prenatal care and accessibility, the quality of the process, measured by criteria and indicators expressed by the Prenatal and Birth Humanization Program, has a high level of inadequacy. Stood out as factors contributing to the low quality of prenatal care: the failure to perform routine laboratory tests, the recommended basic procedures and the lack of guidance during consultations. When these variables were added together through the process indicators for prenatal qualification, they pointed to a significant drop in the adequacy ratios to prenatal care.

The prenatal care provided by SUS in the city of

\section{References}

1. Tsunechiro MA, Lima MOP, Bonadio IC, Corrêa MD, Silva AVA, Donato SCT. Avaliação da assistência pré-natal conforme o Programa de Humanização no Pré Natal e Nascimento. Rev Bras Saúde Mater Infant. 2018; 18 (4): 771-80

2. Brasil. Ministério da Saúde. Secretaria de Atenção à Saúde. Departamento de Ações Programáticas Estratégicas. Área Técnica de Saúde da Mulher. Pré-natal e Puerpério: atenção qualificada e humanizada - manual técnico. Brasília, DF 2005

3. Brasil. Ministério da Saúde. Secretaria de Atenção à Saúde. Departamento de Atenção Básica. Caderno de atenção básica $n^{\circ} 32$ : atenção ao pré-natal de baixo risco. Brasília, DF; 2012.

4. Nascimento IB, Pacheco VC, Souza MLR, Pinheiro EB, Silva TR, Fleig R, Silva JC. Assistência pré-natal e resultado perinatal. Rev Bras Prom Saúde. 2017; 30 (2): 187-94.
Joinville according to the PNBHP, despite the almost universal accessibility, the early start of prenatal care, and the prevalence of respondents with 6 or more prenatal consultations, keeps low levels of adequacy in most criteria and when the criteria are checked together, there is a sharp decline in the adequacy of this care.

Thus, it was evidenced that the prenatal care provided by SUS in the city of Joinville cannot be considered adequate, needing to be improved significantly in several aspects of care, mainly in a qualitative way. It is concluded that the evaluation studies of health services prove to be excellent tools for the analysis of conditions related to the quality of prenatal care. Thus, they contribute as an instrument for future studies related to the implementation of new actions, policies, and strategies that promote the improvement of the maternity care services.

\section{Authors' contributions}

Vaichulonis CG and Silva JC contributed to the definition and methodology of the research and writing of the manuscript. Vaichulonis CG, Ribeiro and Silva R, Schroeder Stepic G, Cruz IR, Oliveira LC, Santos KV, Haritsch L, Mazzetti AC and Apati Pinto AI performed the data collection and its analysis and sought bibliography to support the discussion of the results. Silva MF performed a double-checked the database and built the figures and graphics. All authors approved the final version of this article.

5. Mucha F, Franco SC, Silva GAG. Frequência e características maternas e do recém-nascido associadas à internação de neonatos em UTI no município de Joinville, Santa Catarina - 2012. Rev Bras Saúde Mater Infant. 2015; 15 (2) 201-8.

6. Gonzaga ICA, Santos SLD, Silva ARV, Campelo V. Atenção pré-natal e fatores de risco associados à prematuridade e baixo peso ao nascer em capital do nordeste brasileiro. Ciênc Saúde Coletiva. 2016; 21(6): 1965-74.

7. WHO (World Health Organization). Recommendations on antenatal care for a positive pregnancy experience. Geneva; 2016.

8. ODM (Objetivos do Desenvolvimento do Milênio). O Brasil e os objetivos do desenvolvimento do milênio. 2015 [acesso 17 nov 2019]. Disponível em: http://www.odmbrasil.gov.br/o-brasil-e-os-odm 
9. Brasil. Departamento de Informática do SUS - DATASUS [internet]. Informações de Saúde. Estatísticas vitais: banco de dados. [acesso em 12 set 2019]. Disponível em: https://datasus.saude.gov.br

10. Medici A. 26 anos de SUS: avanços e desafios. 2014 [acesso 20 nov 2019]. Disponível em: http://cebes.org.br

11. Organização das Nações Unidas. Cúpula das nações unidas sobre o desenvolvimento sustentável: agenda 2030. Geneva; 2015. [acesso 15 nov 2019]. Disponível em: www.nacoesunidas.org

12. Brasil. Ministério da Saúde. Portaria $n^{\circ} 569$ de 01 de junho de 2000. Institui o Programa de Humanização no Pré-Nata e Nascimento, no âmbito do Sistema Único de Saúde. Diário Oficial da União, Brasília, DF); 8 de junho de 2000, seção 1, p.4-6

13. Brasil. Ministério da Saúde. Portaria $n^{\circ} 1.459$, de 24 de junho de 2011. Institui no âmbito do Sistema Único de Saúde - SUS - a Rede Cegonha. Brasília, DF; 2011. Diário Oficial da União, Brasília, DF; 27 de junho de 2011, seção 1, p.109.

14. Brasil. Ministério da Saúde. Secretaria de Atenção à Saúde. Departamento de Atenção Básica. A melhoria contínua da qualidade na atenção primária à saúde: conceitos, métodos e diretrizes. Brasília, DF; 2010.

15. Vettore MV, Dias M, Vettore MV, Leal MC. Avaliação da qualidade da atenção pré-natal dentre gestantes com e sem história de prematuridade no Sistema Único de Saúde no Rio de Janeiro, Brasil. Rev Bras Saúde Matern Infant 2013; 13 (2): 89-100.

16. Malta DC, Duarte EC, Escalante JJ, Almeida MF, Sardinha LM, Macário EM, Monteiro RA, Neto OLM. Mortes evitáveis em menores de um ano, Brasil, 1997 a 2006: contribuições para a avaliação de desempenho do Sistema Único de Saúde. Cad Saúde Pública; 2010; 26: 481-91.

17. Brasil. Ministério da Saúde. Secretaria de Vigilância em Saúde. Programa Nacional de Imunizações 30 anos Brasília, DF; 2003.

18. Silva DC, Alvim NAT, Figueiredo PA. Tecnologias leves em saúde e sua relação com o cuidado de enfermagem hospitalar. Esc Anna Nery. 2008; 12 (2): 291-8.

19. Coelho MO, Jorge MSB. Tecnologia das relações como dispositivo do atendimento humanizado na atenção básica à saúde na perspectiva do acesso, do acolhimento e do vínculo. Ciênc Saúde Coletiva; 2009; 14 (1): 1523-31.

20. Domingues RM, Hartz ZM, Dias MA, Leal MC. Avaliação da adequação da assistência pré-natal na rede SUS do Município do Rio de Janeiro, Brasil. Cad Saúde Pública. 2012; 28 (3): 425-37
21. Mendes RB, Santos JMJ, Prado DS, Gurgel RQ, Bezerra FD, Gurgel RQ. Avaliação da qualidade do pré-natal a partir das recomendações do Programa de Humanização no Prénatal e Nascimento. Ciência \& Saúde Coletiva. 2018; 25 (3): 793-804.

22. Viellas EF, Domingues RMSM, Dias MAB, Gama SGN, Theme Filha MM, Costa JV, Bastos MH, Leal MC. Assistência pré-natal no Brasil. Cad Saúde Pública. 2014; 30 (1): S85-S100.

23. Gonçalves CV, Cesar JA, Mendoza-Sassi RA. Qualidade e igualdade na assistência ao gestor: um estudo de base populacional no Sul do Brasil. Cad Saúde Pública. 2009; 25 (11): 2507-16.

24. Piccini RX, Facchini LA, Tomasi E, Thumé E, Silveira DS, Siqueira FV, Rodrigues MA, Paniz VV, Teixeira VA. Efetividade da atenção pré-natal e de puericultura em unidades básicas de saúde do Sul e do Nordeste do Brasil. Rev Bras Saúde Matern Infant. 2007; 7 (1): 75-82.

25. Miranda AE, Trindade CR, Nunes RH, Marba EF, Fernandes MC, Quarto GHA, França LC. Factors associated with prenatal care and seeking assistance in public hospitals in Vitória, Espírito Santo, Brazil. Women Health. 2010; 50: 229-40.

26. Martinelli KG, Santos Neto ET, Gama SGN, Oliveira AE. Adequação do processo da assistência pré-natal segundo os critérios do Programa de Humanização no Pré Natal e Nascimento e Rede Cegonha. Rev Bras Ginecol Obstet. 2014; 36 (2): 56-64.

27. Trevisan MR, De Lorenzi DRS, Araújo NM, Ésber K. Perfil da assistência pré-natal entre usuárias do Sistema Único de Saúde em Caxias do Sul. Rev Bras Ginecol Obstet. 2002; 24: 293-9.

28. Ribeiro ERO, Guimarães AMDN, Bettiol H, Lima DDF, Almeida ML, Souza L, Silva AAM, Gurgel RQ. Risk factors for inadequate prenatal care use in the metropolitan area of Aracaju, Northeast Brazil. BMC Pregnancy Childbirth. 2009; 9: 31

29. Carvalho DS, Novaes HMD. Avaliação da implantação de programa de atenção pré-natal no município de Curitiba, Paraná, Brasil: estudo em coorte de primigestas. Cad Saúde Pública. 2004; 20 (2): S220-30.

30. Silveira DS, Santos IS, Costa JSD. Atenção pré-natal na rede básica: uma avaliação da estrutura e do processo. Cad Saúde Pública. 2001; 17 (1): 131-9.

Received on June 23, 2020

Final version presented on November 23, 2020

Approved on February 18, 2021 